\title{
Investigating the Generic Features of the Sudanese Judicial Precedents
}

\author{
Yasir Mohamed Mohamed Elhassan \\ Faculty of Languages \& Translation, Najran University, Sharourah, KSA
}

\begin{abstract}
This study aims at investigating the Sudanese criminal and civil judicial precedents so as to gain a better understanding of the communicative purposes of each subgenre and the variation in demands across the two subgenres using genre analysis. It adopted the mixed approach, using Maxqda application, to investigate the generic features, the moves, the sub-moves; as well as how problems are solved and decisions arrived at. The investigation shows that the law practitioners should know the intrinsic nature of these judicial precedents by examining their generic features, concepts, functions and approaches. Also, the analysis of the typical generic moves and sub-moves clearly reveals that the judicial precedents across the two subgenres have some overlapping generic structures at all levels. Most of the judicial precedents in the corpus seem to have the typical generic move structures. The analysis of the specific generic move structures reveals slight generic differences of judicial precedents. Finally, there are still evidences of slight variation across the two subgenres at sub-move level.
\end{abstract}

Index Terms - genre analysis, generic features, moves, discourse analysis

\section{INTRODUCTION}

Legal language like all specific genre of language is full of words, phrases, clauses and sentences that have particular meanings. Bhatia (1993) explains that his language has a number of distinctive genres depending on the communicative purposes they intend to maintain in different of legal settings such as cases and judgments, (p. 101). Bazerman and Paradis (1991) argue: "by understanding texts within the professions, we understand how the professions constitute themselves and carry out their work through texts"(p. 12). Legal cases are considered the most significant part of law for specialists in the legal field whether they are students of law or practicing lawyers because the courts follow their previous judgments within more or less well defined limits. So, if the material facts are the same, the cases must be decided in the same way. Such cases are called precedents and they are regarded as re-usable documents, (Harris, 2007, p. 39). Cases also are used rather than legislative texts and focus is put on their narrative features. They have four communicative purposes: to record all the elements of a trail, to serve as precedents to subsequent cases, as a reminders to be used in class or in a court of law and as illustrations of a certain point of law in law course books, (Bhatia,1993, p. 119).

According to Tiersma (1993), "Few professions are as concerned with language as is the law" (p. 113). This idea may help to understand the increasing interest of legal professionals in the study of language, as well as the interest of linguists in the investigation of the language used in legal contexts. The complexity and technicality of the legal language present a challenge to those involved with the education of legal practitioners as well as ordinary people. For this reason, great efforts in the study of legal language have been growing recently. Gibbons (2003) believes that: "whatever the technique used, the linguist would clarify and make more concrete and explicit the basis for [judicial] deciding, and in some cases might provide useful additional information" (p. 297). Thus, such language often poses problems for those familiar and unfamiliar with it; and more difficult for non-native English - speaking lawyers. An awareness of some of the typical features of this language can make it easier to understand its texts, (Linder, 2006, p. 31). This study deals with the judicial precedents published in the Sudan Law Journal and Reports (SLJR) between 1956 and 1966 for the first period and between 1998 and 2008 for the second one. Therefore, a number of questions have been raised in investigating this problem:

1- What are the generic features of the judicial precedents published in the Sudan Law Journal and Reports (SLJR) in the two periods investigated?

2- Are there any significant generic differences between criminal and civil judicial precedents?

3- What are the socio-cultural linguistic features that indicate subgenre type in these judicial precedents?

\section{LITERATURE REVIEW}

Genre analysis has been treated today as an extension and the latest development of the traditional discourse analysis, which is generally well known in the field of Linguistics as a study of language use beyond the sentence boundaries. It expands linguistic analysis from linguistic description to explanation taking into account both the socio-cultural and psycho-linguistic factors. The explanation of this kind of language is of great value to the understanding and construction of professional and academic genres because it reveals both the communicative goals of the discourse 
community in question and the individual strategies employed by the members to achieve these goals, (Bhatia, 1993, p. 39).

\section{A. Moves and Structures in Genre Analysis}

Genre analysis is also an explanation of why language is used differently within specific cultures and a demarcating of this specific language into smaller elements called moves, (Bawarshi and Jo Reiff, 2010, p. 48). A move, to Swales (1981), is a text segment that consists of a package of various linguistic features such as lexicon, syntax, and illocutionary propositions that are responsible for providing the given segment a uniform orientation and signal the content of the discourse, (p. 39). These moves can be inferred through context, but they are mainly examined with reference to their linguistic clues. Besides, a move within a text can be considered any portion of that text that is either written or spoken and achieves a particular function within that text. Moves are considered consequential because while the language of a genre as a whole is useful, the specific language associated with each move must also be considered if a writer is to be wholly accepted by the genre community (Henry and Roseberry, 2001a). The basic principle that underlies genre analysis then is that specific moves and structures within a text can be isolated and examined to discover the structure of certain genres with reference to their allowable move order, move construction, and linguistic features. The ability to identify these key linguistic structures allows for a greater understanding permitting it to be passed on to others outside of the genre in order to help in their understanding and eventual assimilation into the genre, (Grossley, 2007, p. 4). In this study, the move structure of the judicial precedents, namely, identifying the case, establishing facts of the case, arguing the case, and pronouncing judgment, serve as textual marks for move recognition (Bhatia, 1993, p. 127).

\section{B. The General Characteristics of Legalese}

With reference to its rich historical background, legal English is a most interesting and, at the same time, exceptionally complex legal jargon. Legalese is characterized by its specific grammar and archaic lexicon, as well as its great wordiness, and general fuzziness, (Thorne, 1997, p. 328-330). A number of scholars - (Butt and Castle, 2006), (Crystal , 1970), (Garner, 2002), (Mason, 2016), (Mckay and Charlton , 2005), (Tiersma, 1999) - sum up the main characteristics of legalese as it follows: Unfriendly design and layout; solid blocks of dense text with scarce punctuation, overuse of capitalizations, deficiency of white space and margins, decorative Gothic fonts; specific patterns of reference; using archaic adverbs and referential modifiers which are often imprecise and misleading, avoidance of pronouns; use of shall; often in several distinct meanings within one document; frequent use of passive voice, subjunctive, and nominalization; wordiness; using tautological phrases conjoining words of the same meaning; profusion of foreign and sophisticated vocabulary, especially French and Latin; high level of complexity; alarmingly low results in readability tests; ritual character, great repetitiveness of fixed phrases and ready-made formulas; and general resistance to change. Such characteristics make this legal language to be a disputable area among linguists and law practitioners. They complain a lot about the difficulty of this language and its complexity, (Albahi, 2001, p. 7). That legal Arabic language includes embedding sentences, complex grammatical syntactic structure of sentences and excessive use of passive construction and terms that are rarely used in everyday language of today, (Alhamed, 2000, p. 13). Also, Farghal and Shunnaq (1992) when sum up the main features of legal texts they claim that the sentences of both Arabic and English legal texts are long and complex, (Cited in Shunnaq, 2006).

\section{Judicial Precedents and Their Communicative Purposes}

Judicial precedents are considered as the most important part of a law specialist's reading list whether he/she is a law student or a practicing lawyer. Feak and Reinhart (1990) believe that reading and understanding cases help practitioners to acquire knowledge of an entire area of law, (Cited in Orr, 2002, p. 8). Precedents are important because courts follow their previous judgments within more or less well-defined limits, (Bhatia, 1993, p. 118). Walenn (2009) defines them as: "the principle whereby judges are required to follow the decisions made in previous cases which have sufficient similarity" (p. 19). So, a judicial precedent provides stability and consistency within the legal system. Bhatia (1993) considers legal cases, in general, as "the most potent instrument to train the learner of law in legal reasoning, argumentation and decision" (p. 19). Accordingly, He assumes four major communicative purposes that legal cases serve:

1. In their full form, they serve as authentic records of past judgments.

2. They also serve as precedents for subsequent cases, and are generally used as evidence in favor of or against a particular line of argument or decision.

3. Cases serve as reminders to legal experts, who use them in their arguments in the classroom or in the court of law.

4. Moreover, they serve as illustrations of certain points of law.

\section{The Structural Interpretation of Judicial Precedents}

The judicial precedent, like each genre, shows a typical cognitive structuring which accounts for the structural interpretation of the case as Bhatia (1993) claims, it has a typical four-move structure, these are: Identifying the Case, Establishing Facts of the Case, Arguing the Case and Pronouncing Judgment, (p. 127). In the structure of the legal case, all these four moves are more or less obligatory. Cases may vary in the amount of detailed information included, and 
also in choice of sub-moves, which are not obligatory. The structure depends on the purpose that a particular case is meant to serve., (Bhatia, 1993, p. 136).

\section{METHODOLOGY}

To investigate the complexity and the variety of these judicial precedents involved in this study, a mixed methods research is required with the support of Maxqda, a qualitative analysis software. The precedents will be closely looked at even at a different - category levels, criminal and civil, to demonstrate if there are any significant variations. This will be done according to a wide range of criteria, such as generic structures of cases, socio-cultural features, rhetorical mapping, etc. as well as how problems are solved and decisions arrived at; following the seven steps of analysis recommended, (Bhatia, 1993, p. 22), (Bhatia, 2004, p. 196).

\section{A. Population and Sampling}

The study population consists of 967 legal cases, comprising judicial precedents published between 1956 and 1966 for the first period; and from 1998 to 2008 for the second period. All these judicial precedents published in 22 issues of the SLJR and were collected to represent the study population. Then, 48 cases from the two trends were randomly chosen to give representative sample to the study. The aim was to reach a balanced mix of text types so that the results would cover typical and central aspects of the language and the move structure of the Sudanese judicial precedents.

\section{B. Procedure of Analyzing Text as Genre}

To analyze the data obtained, the researcher used Maxqda program, which supports all individuals performing qualitative data analysis, and helps to systematically evaluate and interpret texts. It is also a powerful tool for developing theories and testing the theoretical conclusions of the analysis. It is used in a wide range of academic and non-academic disciplines, https://www.maxqda.com/.

The chosen texts of the criminal and civil judicial precedents were analyzed in terms of generic and socio-cultural features, text-patterning and structural organization of a text- following the seven steps of analysis recommended by Bhatia (1993, p. 22; 2004, p. 164): First, place the given genre-text in a situational context in order to arrive at an explanation of the way the genre is conventionally written. Second, research existing literature on the genre in question and discussions of the ideology of the community use that genre. Third, refine the situational / contextual analysis. Fourth, select a corpus. Fifth, examine intertextual and interdiscursive perspectives. Sixth, do an ethnographic analysis of the conceptions of participants. Finally, study its institutional context, (Bawarshi and Jo Reiff, 2010:47).

\section{DAta Presentation, ANALysis AND DisCUSSION}

\section{A. Data Presentation}

The following table 4:1 shows a summary of the data collected from the two subgenres:

TABLE 4:1

SUMMARY OF DATA COLLECTED

\begin{tabular}{|c|c|c|}
\hline Data Item & Data Items No. & Details \\
\hline \hline $\begin{array}{c}\text { Judicial Precedents between 1956 and } \\
1966\end{array}$ & 24 Judicial Precedents & Words: \\
\hline $\begin{array}{c}\text { Judicial Precedents between 1998 and } \\
\text { 2008 }\end{array}$ & 24 Judicial Precedents & 28,729 \\
\hline Total & 48 Judicial Precedents & 54,510 \\
\hline
\end{tabular}

1. The Judicial Precedent Contents

Judicial precedents whether they are civil or criminal are typically presented as narratives that contain real key elements such as, characters, events, choices, actions, problems and issues, and background information about these elements. Therefore, Judicial Precedents may be short as shown in table 4:2, simple or complex, contain a single issue or several issues. Their common factor is that they provide a means for analyzing data, identifying problems and making decisions.

The structure of a judicial precedent depends on the nature of the case and its purpose. Judicial Precedents also vary in terms of the volume and complexity of elements (characters, events, choices, actions, problems, issues and facts). Some Judicial Precedents provide large data; others give little detailed information. Some of them, like short stories, are brief (less than 300 words) others, are more like organizational biographies; novels and trilogies.

2. Judicial Precedent Presentation

The data show that these judicial precedents have a number of common features a cross the two subgenres. First, there is a reference to appendices such as references, medical reports, laboratory reports, registration forms and maps. These are used as documents in judicial precedents a long with court evidence, such as, weapons, clothing, etc. The judge numbers them in the order of their appearance in the judicial precedent. Second, all the judicial precedents include relevant facts; not only events that happened, but also how the people involved perceived them. Judges use a 
commentary to point or raise some basic issues or questions. Third, the inclusion, of decisions, adds interest to a judicial precedent and helps crystallizing the professionals' thinking. Finally, there is a published source, the judicial precedents also indicate the source when an entire judicial precedent is based on published material, such as the codes, medical reports, the Sudanese Law Journal and Reports (SLJR), the English precedents and law references. They also use direct quotes from references and former precedents relevant to problems or disputes checked.

3. The Difference between the Criminal and the Civil Cases

Criminal cases are different from civil cases in several ways. For example, civil cases deal with disputes between persons who may be individuals or corporations. The theory is that the state acts as a neutral rule-setter and arbiter, but cases are brought by or on behalf of aggrieved persons who want some sort of remedy for something. On the other hand, criminal cases deal with allegations that people have committed crimes, i.e. forms of behaviour that the state has banned. The criminal cases are usually brought by an agency of the state, although there can also be criminal cases brought privately as private prosecutions. Thus, the fundamental difference is that civil law is private, while criminal law is public. Civil law regulates interactions between individuals (and groups of individuals) whereas a criminal action is brought by the state against the defendant, (Mason , 2016, p. 13).

\section{B. Data Analysis and Discussion}

1. The Generic Structures of the Judicial Precedents

\section{a. The Typical Generic Structure of the Judicial Precedents}

Most of the judicial precedents in the area investigated have the following moves: First, it is an Opening Paragraph and/or Background Information (Specific Area of Interest/ Context). This an introductory paragraph usually focuses on the whole case as decided in the first instance courts, giving the reader an insight about it, restating the facts and the decisions appealed. Next, the judicial precedent moves on to deal with the detailed Background Information of the legal case as a whole. It gives the reader the name(s), place(s), the situation(s) and a more detailed description of the specific area in an organization in which decision makers are employed. Then, the judicial precedents move to specific problem and/or specific decision. They contain further details about the issue referred to in the context leading to the discussion of specific problems and/or specific decisions. This is followed by presentation of data and then data process which includes Assessing Information, Application of Concepts |Theories| Principles, Giving Opinions and/or Making Assumptions. Finally, the judicial precedents often contain a closing section that takes the reader back to the opening paragraph(s) summing up and closing the problem or the dispute by making a decision.

b. The Typical Generic Structure of Judicial Precedents: Subgenres Realization

The move structure is the same in all judicial precedents, whether they are civil or criminal. However, cases in different disciplines represent different realities with reference to contexts.

2. The Sub-generic Characteristics

This section examines the moves in the two specific subgenres represented in the area investigated to illustrate to what extent these moves vary in frequency and the way they are presented across these two subgenres from one genre.

TABLE 4:2

FREQUENCY OF COMMON GENERIC MOVES IN CIVIL AND CRIMINAL JUDICIAL PRECEDENTS FOR BOTH PERIODS

\begin{tabular}{|c|c|c|c|c|}
\hline Common generic move & $\begin{array}{c}\text { Criminal 1956- } \\
1966 \% \\
\end{array}$ & $\begin{array}{c}\text { Civil } \\
1956-66 \% \\
\end{array}$ & $\begin{array}{c}\text { Criminal 1998- } \\
2008 \% \\
\end{array}$ & $\begin{array}{c}\text { Civil } \\
1998-2008 \% \\
\end{array}$ \\
\hline Background Information & 41 & 23 & 50 & 34 \\
\hline Identifying Issues/Problems & 9 & 8 & 6 & 7 \\
\hline Presentation of Data & 11 & 29 & 12 & 20 \\
\hline Assessing Information & 14 & 11 & 10 & 12 \\
\hline $\begin{array}{l}\text { Application of CTP (Concepts; Theories, } \\
\text { Principles) }\end{array}$ & 8 & 3 & 7 & 5 \\
\hline Making Assumptions & 3 & 6 & 5 & 4 \\
\hline Giving Opinions & 14 & 20 & 10 & 18 \\
\hline Total & 100 & 100 & 100 & 100 \\
\hline
\end{tabular}

It can be seen from Table 4:2, that all the moves are similar; they are somewhat different in terms of frequency and the way they are presented. The criminal subgenre makes more use of Background Information (41\%) for the first trend and $(50 \%)$ for the last trend comparing with the civil subgenre (23\%) for the first period and (34\%) for the last period.

3. Background Information

Background information as shown in table 4:2, is used more frequently in criminal judicial precedents (41 and $50 \%)$ than in civil judicial precedents (23 and 34\%). Background Information about people are involved in certain legal problem or dispute, and background information about time of the case when it was claimed before the court : 
TABLE 4:3

FREQUENCY OF BACKGROUND INFORMATION SUB-MOVES IN CRIMINAL AND CIVIL PRECEDENTS FOR BOTH PERIODS

\begin{tabular}{|c|c|c|c|c|}
\hline Common Generic Move Sub -Move (Step) & $\begin{array}{c}\text { Criminal 1956- } \\
1966 \%\end{array}$ & $\begin{array}{c}\text { Civil } \\
1956-1966 \%\end{array}$ & $\begin{array}{c}\text { Criminal 1998- } \\
2008 \%\end{array}$ & $\begin{array}{c}\text { Civil } \\
1998-2008 \%\end{array}$ \\
\hline \hline General Background about Case & 66 & 56 & 64 & 13 \\
\hline Background Information about People & 14 & 10 & 23 & 11 \\
\hline Background Information about Time & 20 & 34 & 19 & 100 \\
\hline Total & 100 & 100 & 100 \\
\hline
\end{tabular}

From the table 4:3, it seems that criminal as well as civil judicial precedents in both periods $(66,56,64$ and $70 \%)$ put the greatest emphasis on the general background about the case itself, (14, 10, 13 and 11\%) on people, and (20, 34, 23 and $19 \%$ ) on time. So, there are no significant differences among them. The two subgenres put the greatest emphasis on the case because the most important reason for bringing the case to the Supreme Court is to make sure whether the court of the first instance has applied the law correctly or not. Also, both of them put some emphasis on people because the law is a rule of human conduct.

a. Background Information about People

Both, the civil and the criminal judicial precedents appear to be very detailed and specific when giving facts. However, people's names are involved themselves in criminal judicial precedents, particularly during the second period (1998-2008), are often less specific than those in both criminal and civil judicial precedents of the first period (19561966). For example, full names and titles such as 'Excellency $M r$.' are usually given to judges of the Supreme Court, while accused's name abbreviated, and the description of individuals is often avoided, sometimes with names even left out together., as for example this extract:

In the Name of Allah, the Most Gracious, the Most Merciful
The Supreme Court
Judges:
Excellency Mr. Dr. Ibrahim Ahmed Othman- the Supreme Court Judge- President
Excellency Mr. Abd Allah Alfadil Esie- the Supreme Court Judge- Member
Excellency Mr. Ranfi Mohammed Ibrahim-the Supreme Court Judge- Member
Sudan Government vs. M. A. A. A. et al.
SC./ CP/390/2004

This new style of the second period is due to the effects of the Islamic Laws on the Sudanese Legal System and can be compared with the following former style from the first period:

\begin{tabular}{|c|}
\hline SUDAN GOVERNMENT vs. MARIAKA BERE \\
(AC.CP.157-1956) \\
\hline
\end{tabular}

Therefore, the descriptions of people in criminal cases and civil cases are slightly different; where the government is a permanent party in criminal precedents, the dispute, on the other hand, is always between individuals in civil precedents. Regarding background information about places, both judicial precedents subgenres often mention not just the court, judges, advocates and people are involved in dispute, but also the town, road, actual property and premises. The presentation of Time in Background Information would appear to vary between the specificities and the generalities in both subgenres. Time is essential for both subgenres where the acceptance or rejection of a case before all courts based on the time. Both criminal and civil judicial precedents appear, to great extent, to be very detailed when giving facts. The reason is that in law there is a vital need to establish or verify the facts as these may be used for conviction or exoneration, thus there is a need to be specific.

A common feature in any legal case is to identify the problem or issue; table 4:4 shows the frequency of Identifying Issues found in the two subgenres:

TABLE 4:4:

FREQUENCY OF IDENTIFYING ISSUES IN CRIMINAL AND CIVIL JUDICIAL PRECEDENTS IN BOTH PERIODS

\begin{tabular}{|c|c|c|c|c|}
\hline Common Generic Move & $\begin{array}{c}\text { Criminal 1956- } \\
1966 \% \\
\end{array}$ & $\begin{array}{c}\text { Civil } \\
1956-1966 \% \\
\end{array}$ & $\begin{array}{c}\text { Criminal 1998- } \\
2008 \% \\
\end{array}$ & $\begin{array}{c}\text { Civil } \\
1998-2008 \% \\
\end{array}$ \\
\hline Identifying Issues/Problems & 8 & 10 & 9 & 8 \\
\hline
\end{tabular}

The results, as seen in table 4:4, indicate that the frequency of the move identifying issue is quite consistent across the two subgenres. Both of them often identify the issues by numbering and listing. Besides, judges always refer to acts, ordinances and laws that must be applied on the disputes sued before them, for instance in this extract: 


\section{SUDAN GOVERNMENT v. ALBERT NAHMIAS}

AC-CR-REV-21-1961

B. Awadalla J. March 8, 1961: - By authority of the Chief Justice, I see no reason to.

I entirely agree both with the trying magistrate and the judge of the High Court that this case is governed by Rent Restriction Ordinance, s. 15.

The argument by the learned advocate for applicant that.......... of the English Landlord and Tenant (Rent Control) Act, 1949, and our Rent Restriction Ordinance, s. 15, are entirely different in their wording. The English section says: "A person shall not as a condition of ........ in addition to the rent." In R. v. Birmingham (West) Rent Tribunal, ex p. Edgbaston Investment Trust [1951] 2 K. B.54, 59, cited by the learned advocate, Hilbery J. said that the word "premium" has a technical meaning and means only...

Expressions such as 'due under a contract' 'plaintiff brought suit', 'held', 'the contract stated that', 'the defendant asked for', 'should be litigated', frequently used in civil precedents, for instance:

\section{AMIN ABDEL MASEEH \& SONS v. MANOLI CHADZOGHLOU \& SON}

AC-APP-13-1962 A promissory note was given by defendant to plaintiff as security for money due under a contract made in Egypt for sale of goods delivered at Port Sudan. The contract stated that the debt was to be paid in Egypt in Egyptian currency and sued upon only in Egypt. Plaintiff resides in Egypt; defendant carries on business in Port Sudan. Plaintiff brought suit on the note against the defendant in Port Sudan. Defendant asked for a stay of proceedings in the Sudan.

Held: Because the transaction between the parties... agreed to themselves that dispute arising there from should be litigated in Egypt........ to try the suit under Civil Justice Ordinance, s. $48 \ldots$

On the other hand, expressions such as 'criminal', 'arrested', 'police' 'convicted', 'offender', 'prisoner' ... etc., are frequently used in criminal judicial precedents, for instance:

\section{SUDAN GOVERNMENT v. FARAH EL DOUD GOUROUN} HC-CR-REV-283-

...and after making a comparative test with the finger-prints of the habitual offenders deposited in the Criminal Investigation Department, he identified the finger-prints of the prisoner as identical. A proclamation was made and the prisoner was arrested in Kosti and was brought before the Police Magistrate, Khartoum. The prisoner denied the whole thing, and on the evidence of the finger-print expert he was convicted of housebreaking into the three houses.

One of the functions of the law is to sort out the factual material in assessing its legal implications and employing a systematic approach to the question. The law gives people rights and duties. Furthermore, the law is to discourse and punish the disregard of rights. All of these account for the less personal approach in the two subgenres when dealing with issues entirely connected with law such as these judicial precedents. However, criminal precedents give a detailed personal description about the people who involved themselves in the crime, for instance:

\section{SUDAN GOVERNMENT v. F. A. G. A.}

MA/GA/Death/3/2008

The Judge Dr. Ibrahim Ahmed Osman: Before Babanousa Criminal Court and during the processing of a crime under S (139) from the Criminal Law 1991 where the accused were the brothers of the convicted F. A. G. A. hereby the application has been brought....... The accused explained that they committed the crime under S (139) against the deceased A. M. G., whom he is the second accused in this due case before us...

It can be seen that not only are personal names used, such as 'F. A. G. A.', 'A. M. G.' but personal pronouns such as 'they', 'he' are also used. The court provides a specific factual situation involving the interaction among 'F. A. G. A', 'A. M. G.' and 'the two brothers'. The example takes the form of a narrative.

4. Presentation of Data

Data appear to be almost of equal importance in all judicial precedents in the two subgenres, as seen in table 4:5.

TABLE 4:5

FREQUENCY OF PRESENTATION OF DATA IN CRIMINAL AND CIVIL JUdiCIAL PRECEDENTS IN Both PERIODS

\begin{tabular}{|c|c|c|c|c|}
\hline Common Generic Move & $\begin{array}{c}\text { Criminal Precedents } \\
1956-1966 \% \\
\end{array}$ & $\begin{array}{c}\text { Civil Precedents } \\
1956-1966 \% \\
\end{array}$ & $\begin{array}{c}\text { Criminal Precedents } \\
1998-2008 \% \\
\end{array}$ & $\begin{array}{c}\text { Civil Precedents } \\
1998-2008 \% \\
\end{array}$ \\
\hline Frequency & 29 & 25 & 24 & 22 \\
\hline
\end{tabular}

However, the ways in which these two subgenres present their data are different, as shown in table 4:6.

TABLE 4:6

FREQUENCY OF SUB-MOVES IN PRESENTATION OF DATA FOR THE TWO SUB- GENRES IN BOTH PERIODS

\begin{tabular}{|l|c|c|c|c|}
\hline \multicolumn{1}{|c|}{ Common Generic Sub-Move } & $\begin{array}{c}\text { Criminal Precedents } \\
1956-1966 \%\end{array}$ & $\begin{array}{c}\text { Civil Precedents } \\
1956-1966 \%\end{array}$ & $\begin{array}{c}\text { Criminal Precedents } \\
1998-2008 \%\end{array}$ & $\begin{array}{c}\text { Civil Precedents } \\
1998-2008 \%\end{array}$ \\
\hline \hline Linear Presentation (Verbal Description) & 89 & 88 & 91 & 9 \\
\hline Non-liner Presentation & 11 & 12 & 13 & 100 \\
\hline Total & 100 & 100 & 100 & \\
\hline
\end{tabular}


Judicial precedents in general use linear format to present their data $(89,88,91$ and $87 \%$ ) with a total absence of equations/ models/ graphs, and they are completely reliant on general description of the data/ facts. There are slight differences, with reference to subgenres investigated in this study, as it can be seen before.

TABLE 4:7

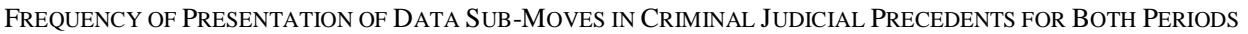

\begin{tabular}{|l|c|}
\hline Common Generic Sub-Move & Criminal Precedents \% \\
\hline \hline General Description of the Data & 98 \\
\hline \hline Tables, Estimations, Graphs, Models, Equations and Figures & 2 \\
\hline Total & 100 \\
\hline
\end{tabular}

Table 4:7 shows that criminal precedents present their data through General Description of the Data (98\%). While Tables, Estimations, Graphs, Models, Equations and Figures represent only (2\%).

On the other hand, table 4:8 shows the frequency of Presentation of Data Sub-Moves in the civil judicial precedents in the first and the last periods:

TABLE 4:8

Frequency of Presentation of Data Sub-Moves in Civil Judicial PreCEDENTS For Both PeRiods

\begin{tabular}{|l|c|}
\hline Common Generic Sub-Move & Civil Precedents \% \\
\hline \hline General Description of the Data & 89 \\
\hline \hline Tables, Estimations, Graphs, Models, Equations and Figures & 11 \\
\hline Total & 100 \\
\hline
\end{tabular}

Table 4:8 shows that civil precedents present their data through General Description of the Data (89\%) while Tables, Estimations, Graphs, Models, Equations and Figures only represent (11\%). Accordingly, judicial precedents, concern with facts whether they are criminal or civil; on the other hand, Tables, Graphs, Models, Equations and Figure help only to illustrate data in case of bringing evidence before a court of law.

5. Assessing Information

Table 4:9 shows a comparison of the frequency of assessing information across the two sub-genres.

TABLE 4:9

FREQUENCY OF ASSESSING INFORMATION IN CIVIL AND CRIMINAL JUDICIAL PRECEDENTS IN BOTH PERIODS

\begin{tabular}{|l|c|c|c|}
\hline Common Generic Move & $\begin{array}{c}\text { Civil Precedents } \\
1956-1966 \%\end{array}$ & $\begin{array}{c}\text { Criminal } \\
\text { Precedents 1956- } \\
1966 \%\end{array}$ & $\begin{array}{c}\text { Civil Precedents } \\
1998-2008 \%\end{array}$ \\
\hline Assessing Information & 6 & 14 & 8 \\
\hline
\end{tabular}

Criminal precedents come to the fore when assessing information (14 and 12\%) comparing with the civil precedents (6 and $8 \%$ ), as shown in table 4:9. Because facts must be determined and proved beyond reasonable doubt in order to convict. It does this through examining the evidence or the facts presented as they relate to laws already established in criminal judicial precedents.

With expressions such as "the accused who released according to", "non-sufficient evidence to prove accusation under", ; the criminal judicial precedents thus relate to previously established criminal code (public laws) rather than to acts or rights in civil code (private law) assessing information accordingly.

6. Application of Concepts/ Theories/ Principles

When applying Concepts/ Theories/ Principles, as shown in table 4:10, the criminal judicial precedent, (9 and $10 \%)$ come to the fore when compared with civil precedents ( 8 and $8 \%$ ), as seen in table 4:10. Nevertheless, such differences are not significant; this may be due to the standard of the evidence required for each subgenre.

TABLE 4:10

FREQUENCY OF THE APPLICATION OF CTP IN THE CRIMINAL AND CIVIL JUDICIAL PRECEDENTS IN BOTH PERIODS

\begin{tabular}{|l|c|c|c|}
\hline \multicolumn{1}{|c|}{ Common Generic Move } & $\begin{array}{c}\text { Criminal Precedents } \\
1956-66 \%\end{array}$ & $\begin{array}{c}\text { Civil Precedents } \\
1956-66 \%\end{array}$ & $\begin{array}{c}\text { Criminal Precedents } \\
1998-08 \%\end{array}$ \\
\hline \hline $\begin{array}{l}\text { Application \& CTP (Concepts, Theories, } \\
\text { Principles) }\end{array}$ & 9 & 8 & 10 \\
\hline
\end{tabular}

According to table 4:10, criminal precedents (9 and 10\%) do appeal to concepts of morality and principles as established by laws and judicial precedents. Both judicial precedents when making decisions, they depend on specific theories, concepts and principles. Although they have more flexibility comparing with the rigidity of the criminal 
judicial precedents, both of them establish their decisions on the base of law. The flexibility of the civil judicial precedents can be seen clearly in contractual transaction where conflicts and disputes can be settled according to the parties' well and the contract itself; however, such settlement must be based on law.

7. Making Assumptions

Table 4:11 shows the frequency of making assumptions across the two subgenres. It indicates that making assumptions is done more frequently in civil precedents (7 and 7\%) than in criminal precedents (3 and 4\%).

TABLE 4:11

FREQUENCY OF MAKING ASSUMPTIONS IN CRIMINAL AND CIVIL JUDICIAL PRECEDENTS IN Both PERIODS

\begin{tabular}{|c|c|c|c|c|}
\hline Common Generic Move & $\begin{array}{c}\text { Criminal Precedents } \\
1956-66 \%\end{array}$ & $\begin{array}{c}\text { Civil Precedents } \\
1956-66 \%\end{array}$ & $\begin{array}{c}\text { Criminal Precedents } \\
1998-08 \%\end{array}$ & $\begin{array}{c}\text { Civil Precedents } \\
1998-08 \%\end{array}$ \\
\hline \hline Making assumptions & 3 & 7 & 4 & 7 \\
\hline
\end{tabular}

Hence, judge's speech, for example, as evidenced in the Sudan Government vs. Adao Mohamed Adao MA/TG/645/1999, 'remaining convinced', 'finding himself', 'discovering that' lead, in this criminal precedent, to the assumption that 'finding fresh ideas will become too difficult; therefore, assumptions are often based on the strict rules of some relevant laws such as the criminal law, the criminal procedures and the law of evidence. So, such assumptions are of a more internal nature than, for example, the assumptions in civil precedents which are more flexible. In contrast civil precedents $(7$ and $7 \%$ ) draw their assumptions from the performance of specific private laws using expressions such as 'applicant', 'respondent', 'plaintiff' , 'defendant', 'civil suit', etc. Any assumptions made by the criminal precedents are seen to be based on strict legal rules and concepts rather than any personal opinions. On the other hand, in civil precedents the assumptions can be based on agreed consent as well as the legal rules and concepts.

8. Giving Opinions

Table 4:12 shows the frequency of giving opinions across the two subgenres. Whereas civil precedents (20 and $19 \%)$ and criminal precedents (19 and 18\%), all, to some extent, rank similarly in frequencies when giving opinions. Law in general, is less inclined to give opinions because it relies on rules, principles and acts, etc., rather than personal opinion. However, there are slight differences between the two subgenres, criminal precedents (19 and 18\%) and civil precedents (20 and 19\%). Such differences are due to the procedural variations between the criminal cases and the civil disputes.

TABLE 4:12

FREQUENCY OF GIVING OPINIONS IN CRIMINAL AND CIVIL JUDICIAL PRECEDENTS IN BOTH PERIODS

\begin{tabular}{|l|c|c|c|c|}
\hline Common Generic Move & $\begin{array}{c}\text { Criminal Precedents } \\
1956-66 \%\end{array}$ & $\begin{array}{c}\text { Civil Precedents } \\
1956-66 \%\end{array}$ & $\begin{array}{c}\text { Criminal Precedents } \\
1998-08 \%\end{array}$ & $\begin{array}{c}\text { Civil Precedents } \\
1998-08 \%\end{array}$ \\
\hline \hline Giving Opinions & 19 & 20 & 18 & 19 \\
\hline
\end{tabular}

a. Giving General Opinions

Table 4:13 indicates the frequency of giving general opinions, making predications and making recommendations in the two subgenres.

TABLE 4:13

FREQUENCY OF SUB-MOVE GIVING OPINIONS IN CRIMINAL AND CIVIL PRECEDENTS IN BOTH PERIODS

\begin{tabular}{|l|c|c|c|c|}
\hline \multicolumn{1}{|c|}{ Common Generic Sub-Move } & $\begin{array}{c}\text { Criminal Precedents } \\
1956-66 \%\end{array}$ & $\begin{array}{c}\text { Civil Precedents } \\
1956-66 \%\end{array}$ & $\begin{array}{c}\text { Criminal Precedents } \\
1998-08 \%\end{array}$ & $\begin{array}{c}\text { Civil Precedents } \\
1998-08 \%\end{array}$ \\
\hline \hline Giving General Opinions & 76 & 87 & 76 \\
\hline Making Predictions & 2 & 11 & 88 \\
\hline Making Recommendations & 22 & 2 & 10 \\
\hline Total & 100 & 100 & 17 & 100 \\
\hline
\end{tabular}

Outstanding are civil judicial precedents, use of giving general opinions (87 and $88 \%$ ) in the two periods as shown in table 4:13 above. This can be explained by the fact that while civil precedents depend on the application of civil law code, it is also an art based on 'gut feeling', i.e., on personal judgmental intuition resulting in opinions always based on the spirit of law, principles of natural equity and justice and experience of an individual judge.

b. Making Predictions

It can be seen that the civil judicial precedents deal with problems that have financial, economical and contractual dimensions. Therefore, the professionals, whether they are judges or lawyers, try to settle disputes or to give strict judgment on the subject matter. Thus, table 4:13 shows that the presence of predictions appears to be important in civil judicial precedents (11 and 10\%) comparing with criminal precedents ( 2 and $7 \%$ ). The prediction made by civil precedents in the following example is realized by the phrase 'it seems it would be enough if'. In turn, this prediction is based on the question raised by the judge, and causal relationship is realized by the phrase 'But the question whether 
such tools, stock, etc., are necessary to enable the judgment debtor to earn his livelihood'. The following civil judicial precedent gives more details:

NICOLA GEORGALIDES v. HASSAB EL RASOUL YOUNIS

(AC-Revision-2o-1960)

A. M. Imam J......I think...The question: what is judgment debtor's trade or calling is obviously one of fact. But the question whether such tools. stock, etc., are necessary to enable the judgment debtor to earn his livelihood is a question of law. To make them necessaryas such it is not essential that they be directly used in such trade or calling; it seems it would be enough if their use is reasonably incidental to the trade or calling in question... In explaining the meaning of tools..., Mulla...states: "This clause should be liberally interpreted...

Making predictions is the form of giving opinion used by professionals, which draws on the spirit of law and the considerable efforts of others such as the explanation of the meaning of the word "tools".

c. Basis of Giving Opinions

Table 4:14 displays the basis of giving opinions a cross the two subgenres, clearly indicating that both subgenres, to great extent, are equal when they give opinions. They rely mostly on data, (41 and $40 \%$ for criminal precedents, 43 and $41 \%$ for civil precedents). It also becomes apparent that when giving opinions, whether (giving) general opinions, making predictions or making recommendations, civil precedents (42 and 40\%) and criminal precedents (39 and 40\%) rely to a higher degree on concepts, theories and principles than personal opinions which represent (20 and $20 \%)$ for criminal precedents while (15 and 19\%) for civil precedents, as the following table shows:

TABLE 4:14

FREQUENCY OF B ASIS OF GIVING OPINIONS IN CIVIL AND CRIMINAL PRECEDENTS IN Both PERIODS

\begin{tabular}{|c|c|c|c|c|}
\hline Common Generic Sub-Move & $\begin{array}{c}\text { Criminal Precedents } \\
1956-66 \% \\
\end{array}$ & $\begin{array}{c}\text { Civil Precedents } \\
1956-66 \% \\
\end{array}$ & $\begin{array}{c}\text { Criminal Precedents } \\
1998-08 \% \\
\end{array}$ & $\begin{array}{c}\text { Civil Precedents } \\
1998-08 \% \\
\end{array}$ \\
\hline Based on Data & 41 & 43 & 40 & 41 \\
\hline Based on CTP (concepts/ theories/ principles) & 39 & 42 & 40 & 40 \\
\hline Based on Personal Opinions & 20 & 15 & 20 & 19 \\
\hline Total & 100 & 100 & 100 & 100 \\
\hline
\end{tabular}

So, with reference to table 4:14, it can be seen that the criminal judicial precedents give opinions based on CTP. This of course reflects and reveals the nature of the legal genre which relies on principles, concepts and theories established by laws and rules of equity.

\section{The Specific Generic Structure of Judicial Precedents}

To examine the variation of the common generic structures of judicial precedents a cross the two subgenres, here is an exploration of how precedents of the same genre reveal subtle differences on a micro level, namely the specific generic move structures of criminal judicial precedents and civil judicial precedents.

1. Specific Generic Structure of the Criminal and Civil Precedents

The specific generic structure of the criminal and civil judicial precedents begin with an opening paragraph and/or background information, which contains the background information that sets the scene and often indicates the descriptions for the crime committed or the right alleged. Similar to civil precedents, criminal precedents also conform to the generic structure (opening paragraph- specific problem and/or specific decision- presentation of data- data process- closing) underlying several precedents in the corpus, however; they revealed slight differences

The criminal judicial precedents in the corpus of this study show that a title is given to the precedent before discussing the context for the issue. When discussing the context, the type of background information is very detailed, with the specific facts given both material and non-material. Specific problem and/or specific decision always involves arguing the precedent. Closing involves arriving at a judgment, where as data process is always embedded in the moves of Argument the Precedents and Pronouncing Judgment. After identifying the issue, another case is cited and the rules, principles of statutes relating to the case are stated. Then the facts are analyzed in terms of the cited case as well as the rules, principles and statutes related to the case. Finally an opinion or a judgment is arrived at.

Both criminal and civil judicial precedents have a typical formulaic realization, displaying cognitive structuring which accounts for their structural interpretation. The analysis of the corpus shows that of all the generic moves examined (again not necessarily in the same order), arguing criminal and civil judicial precedents (42\%) ranked first, establishing the facts of the precedents $(36 \%)$ second, pronouncing judgment (18\%) third, and identifying the precedent (4\%) last.

Move 1: Identifying the Precedent (4\%)

All the judicial precedents investigated need to be identified before giving the context for the issue. There is also the need to refer to them-and in the same way- as they are referred to by the professional community for the reason that these precedents are quoted and used as evidence in courtrooms and in many other legal contexts.

Therefore, both civil and criminal judicial precedents have a fairly strict and standard way of giving their titles and very often begin with move 1 identifying the precedent, which comprised $4 \%$ of the total generic moves, as shown in this extract: 


\begin{tabular}{|c|}
\hline Mohammed Hamza Gaafar vs. Heirs of Hamad Ata Fadulallh \\
SC/CC/2095/2007 \\
\hline
\end{tabular}

The above was a title in one of the judicial precedents investigated. It is the convention that the two parties involved in a dispute are written on either side of the word (versus) abbreviated in small vs. Criminal judicial precedent is different from civil judicial precedent in the way the parties that involved in the case identified. Whereas the first party in the criminal precedents is always the Sudan Government which represents the people of Sudan since the crimes affect the whole community. Therefore, it becomes the first party represented by the prosecutors or attorney general, e.g.

\begin{tabular}{|c|}
\hline The Sudan government vs. Khalaf Allah Mohammed Ali and Others \\
SC/Revision/ /2003
\end{tabular}

Then, the type of precedent explained, the name of the court it was tried in and the date it was reported. However, there is slight difference between the two trends regarding this Move.

Move 2: Opening Paragraph and/or Background information. Context- Establishing the facts (36\%)

The two subgenres of judicial precedents provide the context for the issue that sets the scene. The way in which the information is presented and the nature of the information are slightly different between the two subgenres. The criminal and civil judicial precedents put greater emphasis on background information, which stands out as a very distinguished move. In this study, the frequency of establishing the facts in both judicial precedents is (36\%), ranking second of all moves, and the information given in judicial precedents seems to be quite important, especially under the common law system where the body of law is based on judicial decisions and customs. This could be explained by the need to establish or verify the facts and to distinguish the material facts relevant to the case. These facts could be used in criminal judicial precedents to convict or to exonerate and in civil judicial precedents to decide which one of the two parties is worth receiving the right alleged before the court. Therefore, both legal material and non-material facts are presented.

The following examples demonstrate that, in order to establish the facts, this move (Establishing the facts) provides much information:

1) detailed description of the incident as mentioned before the court of the first instance:

\section{SUDAN GOVERNMENT vs. BARAKIA WAJO}

$$
\text { AC-CP-163-1958 }
$$

Accused and P.W.1 were talking about a Will left by a deceased aunt of theirs whereby she ordained that her unpaid dowry should go to accused's and P.W. 1's nephew. Accused criticized that will and said the dowry ought to have been left for him and his brother (P.W.1) rather than to their nephew, Deceased interfered and said her deceased aunt had the right to leave her dower to whoever she preferred. Accused then resented the garrulousness of deceased and warned her not to talk about wills which are notthe concern of a woman. Deceased insisted she had the right to speak on the matter, Whereupon accused, getting enraged by deceased's insistence, suddenly collected a burning log of wood, $20 \mathrm{cms}$. thick, and holding it with both hands and with all his might, smote the top of the head of who was then sitting in a stool facing him, and thereby smashed her skull and scattered her brain, Deceased died instantaneously.

2) a description of people:

GEORGE MIKHALI vs. SALIH MUHSIN EL YAMANI
AC-REV-136-1960
Respondent tenant brought an action for recovery of rent paid against the applicant landlord who at the time was outside the
$\begin{aligned} & \text { Sudan. The summons to the applicant was served on his agent, who was authorized to collect rent. } \\ & \end{aligned}$

3) a description of time:

The High Council for Youth and Sport vs. Omer Albakri Abu Haraz and Others
SC/CA/8/2001
The applicant brought this application on 14th January 2001 against the decision issued by the Administrative Supreme
Court on 10th January 2001. So, it is accepted because it has been received in the allowed period.

4) a description of place:

\section{SUDAN GOVERNMENT vs. ZE1NAB HAMAD MOHAMED}

AC-REV-104-1964

MA. Abu Rannat, C.J, June 13, 1964:- On January 3, 1961 at Khartoum two Government cars which were part of the fire brigade fleet collided, and as a result of their collision the plaintiff's son died.

Relevant documents are also included, such as in this example: 


\section{AHMED EL BAKHEIT v. SARKIS IZMIRLIAN}

HC.CS-538-1957

T. S. Cotran D.J. February 15 1960:- On April 27, 1957, the plaintiff agreed to buy from the defendant a tractor and a plough at a price of $£ S . I 400$. The plaintiff paid in cash £S.480 and on May 51957 , "he subscribed two promissory notes for £S.480 and £S440 maturing onOctober 4, 1957, and October 4, 1958 respectively. Later he subscribed two more notes which represented some spares and extra freight which he undertook to pay on account of the goods coming via the Cape due to blockage of the Suez Canal.

It may even include dialogues such as the dialogue between the accused and the judge or the deceased as restated in the following example by the major court:

SUDAN GOVERNMENT v. MARIAKA BERE

AC.CP.157-1956

At his trial on July 7, 1956, accused pleaded not guilty and retracted his confession—this appears on page of the Trial Record. He was convicted by the court under Penal Code, s. 251 , and sentenced to death.

These examples show how important facts are in both, criminal and civil judicial precedents. They Strengthen evidence against accused as in criminal judicial precedents or help in weighing the evidences based on burden of proof as it occurs in civil judicial precedents.

Move 3: Specific problem and/or specific decision (detail about the issue)- Arguing the case (42\%)

The specific problem and/or decision in a judicial precedent involve arguing the case. This move is incorporated with the move data process. Therefore, after establishing the facts of the precedent, very often the move of arguing the precedent follows, which leads to final move pronouncing judgment, i.e., the conclusion of the argument. This move, comprising the largest percentage $(42 \%)$ of all generic moves, is the most complex and important one in judicial precedents. As in criminal and civil judicial precedents, before drawing any conclusion, there must be some tools or analyses applied to examine the issue concerned, which appears to be very crucial to the final decision/conclusion of the precedent. When the arguments are put, three sub-moves or steps emerge: Move 3a (Sub-move One): Giving the history of a case (1\%), move 3b (Sub-move Two): Presenting arguments (9\%), and move 3c (Sub-move Three): Deriving the ratio decidendi $(32 \%)$.

Move 4: Closing- Pronouncing judgment (18\%)

After arguing the case, the judicial precedent proceeds to the move Pronouncing Judgment, which comprises (18\%) of all generic moves. The corpus in this study indicates that Move 4 is essential and generally very brief as in this extract:

\section{Sudan Government vs. Musa Ismail and Others} SC/CA/268/1997

Hashim, H, J.:- Accordingly, we see that the decision of the Court of Appeal is hereby set aside and we confirm the decision of the Criminal Court...

The judges use a formulaic form when pronouncing their judgments, for instance:

..... Accordingly, I sentenced .......... In accordance with..........this application is allowed.....

.....this application is dismissed............ concur / I agree.......

A close investigation of the generic structure of the criminal and civil judicial precedents displays arguments and counter arguments either from prosecution counsel and defense counsel or from judges at both higher and lower courts. The main emphasis is based on how the decision was reached, for example, how judges develop principles, and how they apply principles to facts.

\section{CONCLUSION}

This study is based on genre analysis approach to investigate the Sudanese criminal and civil judicial precedents in order to gain a better understanding of the communicative demands of each subgenre and the variation in demands across the two subgenres. The study analyzes the generic features of the Sudanese criminal and civil judicial precedents as well as how problems have been solved and decisions arrived at. The study uses the mixed approach to analyze the corpus and it has come up with the following results:

1. The practitioners, who desire to attain a degree of professionalism, must know the intrinsic nature of the judicial precedents by examining their generic features, concepts, definitions, functions and approaches. All these provide a basis for the function, value, frequency and syntactic realization as well as the specifications of the judicial precedents.

2. The textual perspective of the typical generic moves clearly reveals that the judicial precedents across the two subgenres have some overlapping generic structures at all levels.

3. Most of the judicial precedents investigated seem to have the typical generic move structures as revealed in the analysis. These moves are common in all judicial precedents and appear to be very detailed and specific when giving facts.

4. The Sudanese judicial precedents, in the two periods, rely on a qualitative analysis of legal reasoning and explicit recognition and articulation of a relevant principle of the law or some particular Act. 
5. The textual perspective of specific generic move structures reveals slight generic differences. Although the two subgenres seem a like, there are still evidences of slight variation across them at sub-move level. For instance, under the move of Establishing the Facts, different sub-moves appear across the two subgenres.

\section{REFERENCES}

[1] Albahi, M. (2001). Language and Law. http://www.mmsce.com/stamps.htm (accessed 17/8/2013).

[2] Alhamed, A. (2000). Legal Studies. Khartoum: The Sudanese Dar for Publication.

[3] Bazerman, C. \& J. Paradis. (1991). Textual Dynamics of the Professions: Historical and Contemporary Studies of Writing in Professional Communities. USA: The University of Wisconsin Press.

[4] Bawarshi, A. \& M. Jo Reiff. (2010). Genre- An Introduction to History, Theory, Research and Pedagogy. USA: Parlor Press.

[5] Bhatia, V. K. (2004). Worlds of Written Discourse: A Genre-Based View, London: Continuum International.

[6] Bhatia, V. K. (1993). Analyzing Genre --Language Use in Professional Settings, London: Longman.

[7] Butt, P. \& R. Castle. (2006). Modern Legal Drafting: A guide to Using Clearer Language. New York: Cambridge University Press.

[8] Crossly, S. A. (2007). A Chronotopic Approach to Genre Analysis: An Exploratory Study. English for Specific Purposes, 26(1) (p.4-24).

[9] Crystal, D. \& D. Davy. (1970). Investigating English Style. London: Longman.

[10] Feak, C. \& S. Reinhart (2002). An ESP Program for Students of Law. InT. Orr (ed.) English for Specific Purposes, USA: Teachers of English to Speakers of Other Languages, Inc. (p. 7-23).

[11] Garber, A. (2004). Discourse Analysis of Directive Texts: The Case of Biblical Law. USA: Indiana Elkhart Press.

[12] Garner, A. (2002). The Elements of Legal Style. New York: Oxford University Press.

[13] Gibbons, J. (2003). Review of Cotterill, Janet (Ed.) (2002). Language in the Legal Process. Forensic Linguistics, 10.2, (p.297299).

[14] Harris, P. (2007). An Introduction to Law. New York: Cambridge University Press.

[15] Henry, A. \& R. Roseberry. (2001a). A Narrow-angled Corpus Analysis of Moves and Strategies of the Genre: 'Letter of Application'. English for Specific Purposes, 16, (p.321-337).

[16] Mason, C. (2016). The Lawyer's English Language. UK: Global Legal English Ltd.

[17] Maxqda Software. (2010). https://www.maxqda.com/ (accessed 11/3/2018).

[18] Mackay, W. \& H. Charlton. (2005). Legal English. England: Pearson Education Limited.

[19] Shunnaq, A. (2006). Difficulties of Sight Interpreting of Islamic Court Texts from Arabic into English. The Arab Journal for Arts. Vol. 3 No. 1, p. 1-23.

[20] Swales, J. (1981). Aspects of Article Introductions. Birmingham, UK: Aston University Languages Study Unit.

[21] Swales, J. (1981b). The Function of One Type of Participle in Chemistry Text. In L. Selinker, E. Tarone and V. Hanzeli (eds.), English for Academic and Research Settings.

[22] TESOL Journal: Volume 4, December 2011 Published by the Asian EFL Journal Press Asian EFL Journal Press.

[23] The Sudan Law Journal and Reports: Issues: (from 1956 to 2008). Khartoum. Printing Press of the Judicial Authority.

[24] Thorne, S. (1997). Mastering Advanced English Language. London: Palcrave.

[25] Tiersma, P. (1993). Linguistic Issues in the Law. Lang, 69, (p.113-137).

[26] Walenn, J. (2009). English for Law in Higher Education Studies. UK: Garnet Publishing Ltd.

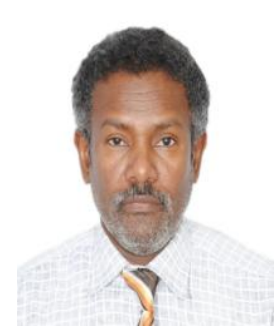

Yasir Mohamed Elhassan was born in Marawi, Sudan in 1967. He received his PhD in Discourse Analysis, from Omdurman Islamic University, Sudan in 2012.

He is currently Assistant Professor in the Faculty of Languages and Translation, Sharourah, at Najran University in KSA. His research interests include Applied Linguistics, Discourse Analysis, Genre Analysis, Legal English and Translation. 